\title{
Sexual development and reproductive pattern of the Mutton hamlet, Alphestes afer (Teleostei: Epinephelidae): a dyandric, hermaphroditic reef fish
}

\author{
Simone Marques and Beatrice Padovani Ferreira
}

There is little knowledge on the reproduction of the genus Alphestes. The reproduction of the Mutton hamlet, Alphestes afer, sampled in Pernambuco reefs (Brazil) was studied based on macroscopic analysis during reproductive period and histological analysis of gonad material from March 2008 to October 2009. This study showed that A. afer is a diandric, protogynous hermaphrodite. Sex change followed protogynous mode in two pathways: primary males formed from immature female individuals or secondary males formed from resting, ripe or spent female individuals. The numerical distribution of gonad classes by size indicated that females from 11-18 $\mathrm{cm} L_{\mathrm{T}}$ were immature while females from 16-25 $\mathrm{cm} L_{\mathrm{T}}$ and males from 12-22 $\mathrm{cm} L_{\mathrm{T}}$ were in various stages of gonadal development. Individuals identified as immature bisexual and transitional (presenting both ovarian and sperm tissue) were sized from 16-24 $\mathrm{cm} L_{\mathrm{T}}$. Size of first reproduction for females was $18 \mathrm{~cm} L_{\mathrm{T}}$ and for males was $12 \mathrm{~cm} L_{\mathrm{T}}$. Alphestes afer showed multiple spawning, with spawning season period from August to December 2008 and from August to October 2009. The sex-ratio (females: males) in 2008 and 2009 was 0.94:1 during the months of spawning season. Males were smaller than females, reaching maximum size of $22 \mathrm{~cm}$ compared to $25 \mathrm{~cm}$ observed for females. Males showed a high sperm competition rank (3.8), suggesting intense sperm competition. This latter is a possible indication of a shift in the mating group structure from paired to group spawning. The presence of small males added to high sperm competition index, suggest that this species, while retaining the protogynous pattern, has a reproductive strategy similar to gonochorist epinephelids.

Há pouco conhecimento sobre a reprodução do gênero Alphestes. A reprodução do sapé Alphestes afer coletado nos recifes de Pernambuco (Brasil) foi estudada baseada em análises macroscópicas durante o período reprodutivo e análises histológicas das gônadas de março de 2008 a outubro de 2009. Esse estudo mostrou que Alphestes afer é uma espécie hermafrodita diândrica. A mudança de sexo seguiu o modo protogínico em dois caminhos: machos primários transformados de fêmeas imaturas ou machos secundários transformados de fêmeas em repouso, maduras ou esgotados. A distribuição numérica por classe de tamanho indicou que fêmeas de 11-18 cm $L_{\mathrm{T}}$ foram imaturas; fêmeas de 16-25 $\mathrm{cm} L_{\mathrm{T}}$ e machos de 12-22 $\mathrm{cm} L_{\mathrm{T}}$ foram de vários estádios de desenvolvimento gonadal. Indivíduos identificados como imaturos bissexuais e transicionais (ambos apresentando tecido ovariano e espermático) foram de $16-24 \mathrm{~cm} L_{\mathrm{T}}$ de comprimento. O tamanho de primeira maturação da fêmea foi $18 \mathrm{~cm} L_{\mathrm{T}}$ e do macho foi $12 \mathrm{~cm} L_{\mathrm{T}}$. Alphestes afer mostrou desova múltipla, com período de desova de agosto a dezembro de 2008 e de agosto a outubro de 2009. A proporção sexual (fêmeas: machos) em 2008 e 2009 foi 0,94:1 durante os meses de desova. Machos foram menores que as fêmeas, alcançando o tamanho máximo de $22 \mathrm{~cm} L_{\mathrm{T}}$ comparados ao tamanho máximo de $25 \mathrm{~cm} L_{\mathrm{T}}$ das fêmeas observadas. Machos tiveram o rank de competição espermática alto $(3,8)$ sugerindo intensa competição espermática, o que é uma possível indicação da mudança na estrutura do grupo de acasalamento de desova em pares para desova em grupo. A presença de machos pequenos com alto índice de competição espermática sugere que esta espécie, enquanto retém o padrão protogínico, possui uma estratégia reprodutiva similar aos epinefelídeos gonocoristas.

Key words: Juvenile sex change, Protogynous hermaphrodite, Reproduction.

Universidade Federal de Pernambuco, Departamento de Oceanografia, 50740-550 Recife, PE, Brazil. simonemarbio@gmail.com 


\section{Introduction}

The groupers (now Epinephelidae, reclassification of Serranidae by Smith \& Craig, 2007) exhibit at least three different sexual patterns: protogynous hermaphroditism, gonochorism and bi-directional sex change (Sadovy de Mitcheson \& Liu, 2008). Although it is often assumed that most of groupers present reproductive strategy of protogynous hermaphroditism, a number of reports have yet to be substantiated and confirmation of sexual pattern is still lacking for many species (Sadovy \& Colin, 1995, Sadovy de Mitcheson \& Liu, 2008). The criteria to diagnose hermaphroditism in fishes in different survey areas have varied widely, but need care to not generate misinterpretations (Sadovy \& Shapiro, 1987). The growing number of reports of hermaphroditic species over the last decade, new perspectives on phylogeny in some groups emerging from molecular studies and clearer criteria for distinguishing functional from non-functional, invite a re-examination of hermaphroditic sexual patterns in teleosts (Sadovy de Mitcheson \& Liu, 2008).

Hermaphroditic fishes could be defined in two categories: i) simultaneous, when the male and female sex cells ripen at the same time; and ii) sequential, which could be protogynous hermaphrodite that function first as females and them transform to males, or protandrous hermaphrodite that transform males into females (Smith, 1959; Yamamoto, 1969; Chan \& Yeung, 1983). The protogynous mode of reproduction is complicated in certain species by the occurrence of some large females that do not change sex and some small males that are mature at the same size as the smallest females (Heemstra \& Randall, 1993, Liu \& Sadovy, 2004).

Many protogynous groupers could exhibit either the monandric or diandric form of protogyny. The first occurs when males develop via only adult sex change (secondary male), while the diandric form is when males develop directly from juvenile sex change (primary male) (Sadovy de Mitcheson $\&$ Liu, 2008).

The importance of determining the mode of reproduction of a species is enhanced by the fact that fishery management is considerably complicated by sequential hermaphroditism (Shapiro, 1987). Since males in protogynous species tend to be larger, older and less numerous than females, fishing may remove more males than females (Ferreira, 1993). There is little knowledge of sexual behavior of small groupers hermaphrodites exploited in fisheries.

The Mutton hamlet, Alphestes afer (Bloch, 1793), is a small grouper (Epinephelidae), shallow-water, cryptically colored fish that is easily overlooked in their typical seagrass habitat (Heemstra \& Randall, 1993). They rarely reach $30 \mathrm{~cm} L_{\mathrm{T}}$ in size and are common in waters between 2 and 50 meters deep (Craig et al., 2006). This small grouper has been recorded from Bermuda, south Florida to southern Brazil (CarvalhoFilho, 1999) and in the Gulf of Guinea, western Africa (Craig et al., 2006).

Apart from the work by Smith (1959) which considered $A$. afer as protogynous hermaphrodite, based in histological analysis of only 8 individuals, there is little knowledge on the reproduction of the genus Alphestes.

The purpose of this work was to assess the reproductive biology of $A$. afer, including description of size distribution of individuals, seasonality of reproduction, sex ratio, and occurrence of sex-change in Brazilian reefs.

\section{Material and methods}

\section{Sampling}

The coast of Pernambuco State, in the Brazilian Northeast, is $187 \mathrm{~km}$ long and characterized by the presence of mangroves, coral reefs and seagrass beds. This coast represents a highly productive system that supports intense artisanal fisheries (Ferreira \& Maida, 2006). In Pernambuco State, the Mutton hamlet, Alphestes afer, is caught frequently by traps and hook and line in costal reefs and over the continental shelf.

Alphestes afer was sampled monthly in four localities on the coast of Pernambuco State: 1) Itamaracá ( $\left.7^{\circ} 44^{\prime} \mathrm{S}, 34^{\circ} 49^{\prime} \mathrm{W}\right)$, 2) Recife ( $\left.\left.8^{\circ} 04^{\prime} \mathrm{S}, 34^{\circ} 52^{\prime} \mathrm{W}\right), 3\right)$ Tamandaré $\left(8^{\circ} 45^{\prime} \mathrm{S}, 35^{\circ} 05^{\prime} \mathrm{W}\right)$ and 4) São José da Coroa Grande ( $8^{\circ} 53^{\prime}$ 'S, 35 $35^{\circ} 08^{\prime} \mathrm{W}$ ) between March 2008 and October 2009. Most samples were obtained during landings from trap fisheries operating over the continental shelf in depths between 30 to $50 \mathrm{~m}$. A smaller percentage of the sample (13\%) was obtained from landings from hook and line fisheries and spear fisheries operating in shallow reefs between depths of 3 to $5 \mathrm{~m}$.

Each fish was measured and weighted. Total length $\left(L_{\mathrm{T}}\right)$ was measured in centimeters $(\mathrm{cm})$ and total weight $(W \mathrm{t})$ in grams (g). Gonads for each individual were removed, weighed (in grams), and fixed in FAAC (formaldehyde $4 \%$, acetic acid $5 \%$, calcium chloride 1.3\%) (Ferreira, 1993). Alternatively, inspection of fresh gonads was conducted macroscopically in order to determine the sex. In this latter case, individuals were classified as either ripe female or male.

After fixation in FAAC, each gonad sample was rinsed with fresh water and then preserved with alcohol $70^{\circ}$. Gonadal tissue was cut from the middle part of the gonadal lobe. After the dehydration process, the gonads were embedded in paraffin, sectioned transversally at 4-5 $\mu \mathrm{m}$ and stained with haematoxylin-eosin (Beçak \& Paulete, 1976).

Maturity stages were determined from histological observations to assess the development of the ovary and testis. Oogenesis and spermatogenesis stages classification followed Nagahama (1983) and Ferreira (1993, 1995); and developmental stages classification followed Chan \& Sadovy (2002) and Liu \& Sadovy (2004).

The spawning season was determined through histological analyses. Gonadosomatic index $\left(I_{\mathrm{G}}\right)$ was calculated as $I_{\mathrm{G}}=W_{\mathrm{Go}} / W_{\mathrm{t}} \times 100$, where $W_{\mathrm{Go}}=$ gonadal weight, and $W_{\mathrm{t}}=$ total weight.

The amount of fat deposited in the mesenteries was estimated following a relative scale from 1 to 3 , which indicated the proportion of fat covering the viscera (1: no visible fat; 2 : increasing amounts of fat, and 3 : fat completely covering the 
viscera). This scale was chosen after an observation of the variation in the amounts of mesenteric fat during reproductive cycle. The estimation was always made by the same observer. This scale was transformed in percentage to compare with $I_{\mathrm{G}}$.

The size $\left(L_{\mathrm{T}} \mathrm{cm}\right)$ of first spawning was determined when $50 \%\left(L_{\mathrm{T} 50}\right)$ of females and males have begun their reproductive cycle. The individuals in each size class from 12 to $26 \mathrm{~cm} L_{\mathrm{T}}$ were either in ripening or ripe gonad stage, thus were grouped per sex. Size distribution of females and males was compared between gonadal stages among reproductive period. Mature females and males were included to calculate the sex-ratio only when reproductively active.

The $I_{\mathrm{G}}$ (gonadosomatic index) of reproductive active males was used as a proxy of sperm competition intensity following a review by Erisman et al. (2009). Mean $I_{\mathrm{G}}$ of breeding males was used to score the intensity of sperm competition, separated in four groups of increasing levels of sperm competition ranks $\left(S_{\mathrm{R}}\right)$ (Table 1$)$.

A nonparametric Kruskal-Wallis ANOVA $(P<0.05)$ was used to examine differences in some analysis among gonadal stages of females and males $\left(I_{\mathrm{G}}\right.$, mesenteric fat, sizes distribution of gonadal stages). Spearman Rank correlation was used to analyze the relationship between $I_{\mathrm{G}}$ and mesenteric fat for mature females and males, and between $I_{\mathrm{G}}$ and size. A Chi-Square test $\left(\chi^{2}\right)$ was used to compare sex ratio (mature females:mature males) between months of reproductive period.

\section{Results}

The total number of individuals collected from landings was 249 , ranging from 12.2 to $25.8 \mathrm{~cm} L_{\mathrm{T}}$. The number of individuals analyzed per month varied between 9 and 22, depending on availability and period of the year. An additional sample of eight small juveniles ( 11.6 to $15.4 \mathrm{~cm} L_{\mathrm{T}}$ ) was collected in shallow reefs ( $3 \mathrm{~m}$ ) of Tamandaré using fence nets between March 2009 and February 2010.

Sex determination was attempted from macroscopic observations only during the reproductive period. All gonads of females and males had an ovarian structure with a lumen and numerous lamellae protruding into the lumen from the dorsal and lateral walls. Six gonadal stages were histological recognized in ovaries and four in the testes. Sex change was

Table 1. $I_{\mathrm{G}}$ of breeding males, sperm competition ranks $\left(S_{\mathrm{R}}\right)$ and sexual pattern of groupers species according to review by Erisman et al. (2009). $S_{\mathrm{R}}$ (1), non aggregating species that spawn in pairs; $S_{\mathrm{R}}(2)$, aggregating species that spawn in pairs; $S_{\mathrm{R}}$ (3), aggregating species that spawn in pairs or groups; $S_{\mathrm{R}}(4)$, aggregating species that spawn only in groups.

\begin{tabular}{ccc}
\hline Mean $I_{\mathrm{G}}$ & $S_{\mathrm{R}}$ & Sex Pattern \\
\hline $0.2-0.5$ & 1 & protogynous \\
$0.6-2.0$ & 2 & protogynous \\
$2.0-4.0$ & 3 & Protogynous or unconfirmed gonochorism \\
$>4$ & 4 & gonochorism \\
\hline
\end{tabular}

determined in juvenile and adult females presenting four stages, so the species was considered a protogynous hermaphrodite. Each gonad was assigned in one of the following phases: immature female; ovarian phase of resting, ripening, ripe and spent female; immature bisexual phase of females; transitional phase of resting, ripe and spent female; testicular phase of ripening, ripe, spent and resting male. Table 2 lists these phases and their corresponding macroscopic and histological characteristics.

During histological analysis, sex changing gonads were identified when sperm crypts appeared. These sperm crypts were confirmed comparing with the spermatogenesis stages of male A. afer (Fig. 3). Individuals with gonads containing previtellogenic oocytes and spermatogenic tissue without signs of previous female function were classified as immature bisexual (Table 2). Mature individuals showing both proliferation of testicular tissue and degeneration of ovarian tissue were considered transitional. Sex changing gonads presented spermatic crypts or groups with spermatides or spermatozoa, located near the edge of gonad wall and spread among ovarian tissue. Also oocytes $(\mathrm{O} 1, \mathrm{O} 2$ or $\mathrm{O} 3)$ in these gonads showed signs of degeneration (Table 3). Muscle bundles (MB) were evident (Table 3; Fig. 4b). The presence of $\mathrm{MB}$, surrounding the blood vessels, was most prominent after spawning in spent females and at the beginning of resting period of females. Sperm sinuses were observed only in transitional individuals on resting stage, and in those individuals larger proliferation of sperm crypts was also observed. Transitional individuals in other stages presented only few sparse sperm crypts (Tables 3,4 ).

Only ten males ( $21 \%$ of all examined individuals) presented residuals previtellogenic oocytes intermingled with testicular tissue (Fig. 2c). These residual oocytes were probably remains from the juvenile bisexual phase with no functional significance.

\section{Size distribution of males and females and size of first maturity}

Immature females measured from 11 to $18 \mathrm{~cm} L_{\mathrm{T}}$ while mature females measured from 16 to $25 \mathrm{~cm} L_{\mathrm{T}}$. Immature bisexual present showed a size range of 16 to $17 \mathrm{~cm} L_{\mathrm{T}}$. Males, including the ones which had residual ovarian tissue, ranged from 12 to 22 $\mathrm{cm} L_{\mathrm{T}}$ (Table 4).

A single small specimen of immature bisexual female Fbi(Im) was identified during May 2008 (Fig. 4a). This specimen did not exhibit any sign of previous female function, such as muscle bundles or later stage oocytes (O2, O3) (Tables 3, 4). Smaller males $\left(12\right.$ to $\left.17 \mathrm{~cm} L_{\mathrm{T}}\right)$ did not show evidence of first reproduction as previous females function. Among twelve resting transitional female $\operatorname{Tr}(\mathrm{Re})$, only two individuals (18 to $19 \mathrm{~cm} L_{\mathrm{T}}$; June 2008 and June 2009) did not show presence of muscle bundle as evidence of previous female function (Table 4). Five individuals between 18 and $24 \mathrm{~cm} L_{\mathrm{T}}$ of ripe and spent transitional females $\operatorname{Tr}(\mathrm{Rp})$ and $\operatorname{Tr}(\mathrm{Sp})$ showed ovarian tissue with evidences of previous female function (Table 3, Fig. 5). These transitionals individuals represented $2.7 \%$ of all females observed. 
Table 2. Description of gonadal stages of Alphestes afer. F (Im): immature female; F: female; Fbi(Im): immature bisexual phase of female; $\operatorname{Tr}(\mathrm{Re})$ : transitional resting; $\operatorname{Tr}(\mathrm{Rp})$ : transitional ripe; $\operatorname{Tr}(\mathrm{Sp})$ : transitional spent; M: male; Mro: male with residual oocytes.

\begin{tabular}{|c|c|c|}
\hline Gonadal Stages & Macroscopic appearance & Histological appearance \\
\hline \multicolumn{3}{|l|}{$\mathbf{F}(\mathbf{I m})$} \\
\hline Immature & $\begin{array}{l}\text { The ovaries in this stage were } \\
\text { pink-translucent and small. }\end{array}$ & $\begin{array}{l}\text { Ovaries were small in diameter and showed no evidence of prior spawning; the gonad wall } \\
\text { was relatively thick; the lamellae was packed and filled with oocytes in early perinucleolus } \\
\text { stage. Gonia and chromatin nucleus stage oocytes were abundant (Fig. 1a). }\end{array}$ \\
\hline \multicolumn{3}{|l|}{$\mathbf{F}$} \\
\hline Resting & $\begin{array}{l}\text { Ovaries were larger than } \\
\text { immature females and usually } \\
\text { pale pink-yellow. }\end{array}$ & $\begin{array}{l}\text { The lamellae presented oocytes in early and late perinucleolus stages; the presence of } \\
\text { yellow-brown bodies was common. Also the presence of muscle bundles in this phase was } \\
\text { used as an indicator for determining previous female function. }\end{array}$ \\
\hline Ripening & $\begin{array}{l}\text { Ovaries were pink yellow and } \\
\text { larger than resting females. }\end{array}$ & Oocytes in vitellogenic stage, from yolk vesicle stage to the beginning of yolk globule stage. \\
\hline Ripe & $\begin{array}{l}\text { The ovaries were large, } \\
\text { yellowish and had a granular } \\
\text { appearance due to the presence } \\
\text { of mature oocytes. }\end{array}$ & $\begin{array}{l}\text { Ovaries presented oocytes in several stages of development, from yolk globule stages to } \\
\text { hydrating stages (Fig. 1b). }\end{array}$ \\
\hline Spent & $\begin{array}{l}\text { The ovaries were flaccid, } \\
\text { bloody, and pale yellow. }\end{array}$ & $\begin{array}{l}\text { Lamellae were disrupted and follicular cells, remnants of pos-ovulatory follicles, were } \\
\text { present throughout the gonad; vitellogenic oocytes were in several stages of atresia. }\end{array}$ \\
\hline Fbi(Im) & $\begin{array}{l}\text { Ovaries was similar to } \mathrm{F}(\mathrm{Im}) \text {. } \\
\text { Ovarian wall was thinner. }\end{array}$ & $\begin{array}{l}\text { Ovaries presented both previtelloginic oocytes and spermatogenic tissue. There was no } \\
\text { evidence of prior spawning.(Fig. } 4 \text { a). }\end{array}$ \\
\hline $\begin{array}{l}\operatorname{Tr}(\operatorname{Re}),(\mathrm{Rp}) \\
(\mathrm{Sp})\end{array}$ & $\begin{array}{l}\text { Macroscopic sex assignment } \\
\text { was not possible in this phase. }\end{array}$ & $\begin{array}{l}\text { Ovary showed degeneration of ovarian tissue and proliferation of testicular tissue (small } \\
\text { crypts or group of spermatozoa) in females in resting, ripe and spent stage (Fig. } 4 \mathrm{~b}, \mathrm{c} \text { ). }\end{array}$ \\
\hline \multicolumn{3}{|l|}{ M } \\
\hline Resting & $\begin{array}{l}\text { Macroscopic sex assignment } \\
\text { was not possible in this phase. }\end{array}$ & $\begin{array}{l}\text { Early stage of spermatogenesis with crypts of spermatogonia, and spermatocytes in first } \\
\text { stage; dorsal sinus was present and filled with some spermatozoa. }\end{array}$ \\
\hline Ripening & $\begin{array}{l}\text { Macroscopic sex assignment } \\
\text { was not possible in this phase. }\end{array}$ & $\begin{array}{l}\text { Presence of crypts containing secondary spermatocytes, spermatides and spermatozoa; } \\
\text { dorsal sinus was present and filled with spermatozoa. }\end{array}$ \\
\hline Ripe & $\begin{array}{l}\text { The testis was large, milky } \\
\text { white due to the presence of } \\
\text { milt filled with spermatozoa. }\end{array}$ & $\begin{array}{l}\text { Crypts of spermatides and spermatozoa, ruptured and joined within the testicular lobules, } \\
\text { forming large intralobular sinuses; dorsal sinuses developed and filled with abundant } \\
\text { spermatozoa (Fig. 2a, b). }\end{array}$ \\
\hline Spent & $\begin{array}{l}\text { Macroscopic sex assignment } \\
\text { was not possible in this phase. }\end{array}$ & $\begin{array}{l}\text { Crypts of spermatogonia and spermatocytes in first stage beginning to appear, spermatozoa } \\
\text { presence reduced to small amounts in intralobular and dorsal sinuses. }\end{array}$ \\
\hline Mro & $\begin{array}{l}\text { Macroscopic sex assignment } \\
\text { was not possible to identify this } \\
\text { phase. }\end{array}$ & $\begin{array}{l}\text { Testicular phase of resting, ripening ripe and spent males with residual primary oocytes } \\
\text { sometimes showing degeneration (Fig. } 2 \text { c). }\end{array}$ \\
\hline
\end{tabular}

The size of first reproduction (considered as the size in which $50 \%$ of individuals are reproductively active) was 18 $\mathrm{cm} L_{\mathrm{T}}$ for females and $12 \mathrm{~cm} L_{\mathrm{T}}$ for males, showing that reproductive males were smaller than females. The modal size of females was $22 \mathrm{~cm} L_{\mathrm{T}}$ while for males was $20 \mathrm{~cm} L_{\mathrm{T}}$ (Fig. 6). Average size of males and females was significantly different (t-test, $\mathrm{df}=62, P<0.05)$.

\section{Seasonality and periodicity of spawning}

Spawning period was evident from August to December 2008 and from August to October 2009 gonadal stages and $I_{G}$. The reproductive peak in August 2009 was more intense than that in August 2008 (Kruskal-Wallis, $\mathrm{df}=1 ; P<0.05$ ). There were significant differences between $I_{G}$ of months of resting period and months of reproductive period of 2008 and 2009 (Kruskal-
Wallis, $\mathrm{df}=19 ; P<0.05)$. There were no significant differences between $I_{G}$ values of mature females and males (Kruskal-Wallis, $\mathrm{df}=1 ; P=0.0554)$. Significant differences were identified in $I_{G}$ values between months of reproductive peak of 2008 and 2009 (Kruskal-Wallis, $\mathrm{df}=5 ; P<0.05)$ (Fig. 7).

The amount of fat deposited in the mesenteries of males and females had significant differences between months (Kruskal-Wallis; $\mathrm{df}=19 ; P<0.05$ ). From January to June 2009, there was an increase in the amount of fat before the reproductive peak. The amount of mesenteric fat observed in September 2008 dropped to zero and remained so until December 2008, after the end of the reproductive period. The decrease of fat was also observed in September 2009 (Fig. 7). The variation in the amount of mesenteric fat was antiphasic to the variation observed in the $I_{\mathrm{G}}$ for males and females (Fig. 

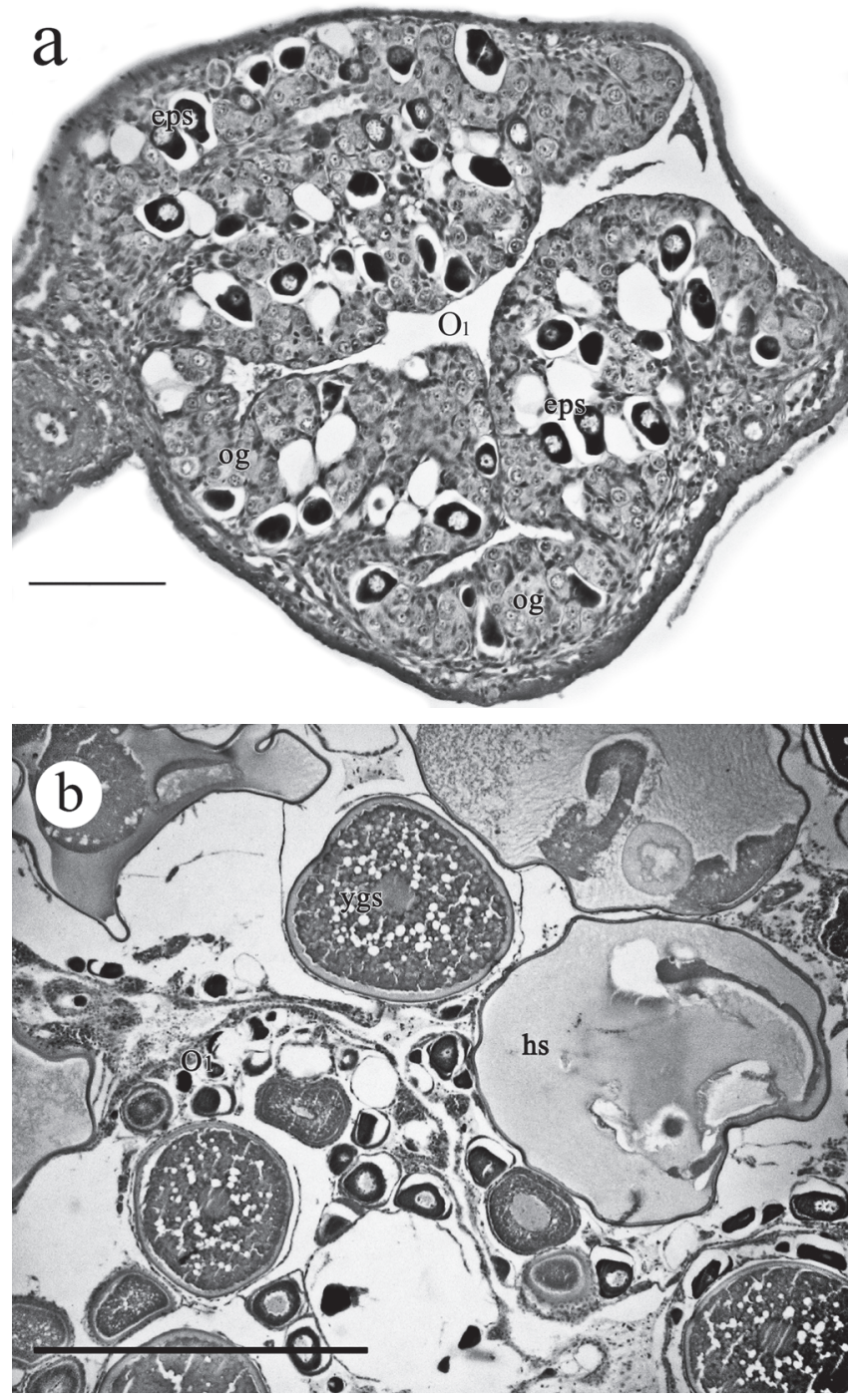

Fig. 1. Photomicrographs of histological sections from females Alphestes afer gonads. (a) Section from a immature female $($ bar $=100 \mu \mathrm{m})\left(11.6 \mathrm{~cm} T_{\mathrm{L}} ;\right.$ February 2010). (b) Section from a ripe female $(\mathrm{bar}=500 \mu \mathrm{m})\left(19.6 \mathrm{~cm} T_{\mathrm{L}}\right.$; October 2009). og = oogonium, eps $=$ early perinucleolus stage, ygs $=$ yolk vesicle stage, hs $=$ hydrated stage, $\mathrm{O}_{1}=$ primary growth stage oocyte .

7), and the amount of fat was inversely correlated with gonad weight for mature females and males (Spearman rank $R_{\mathrm{S}}=$ $0.254 ; P<0.05$ ).

Ripe females were found from August to December in 2008 and from July to October in 2009 (Fig. 8). Ovaries in this stage showed oocytes in maturation, mature and hydrated; previtellogenic oocytes in ripe female were also present (Fig. 1b).

Ripe males were found from July 2008 to February 2009 and from June to October 2009 (Fig. 8). Intense spermiogenesis and the presence of spermatozoa filled sinuses indicated that males could spawn several times. Since the end of reproductive period (December 2008) some mature males showed the beginning of spermatogenesis with
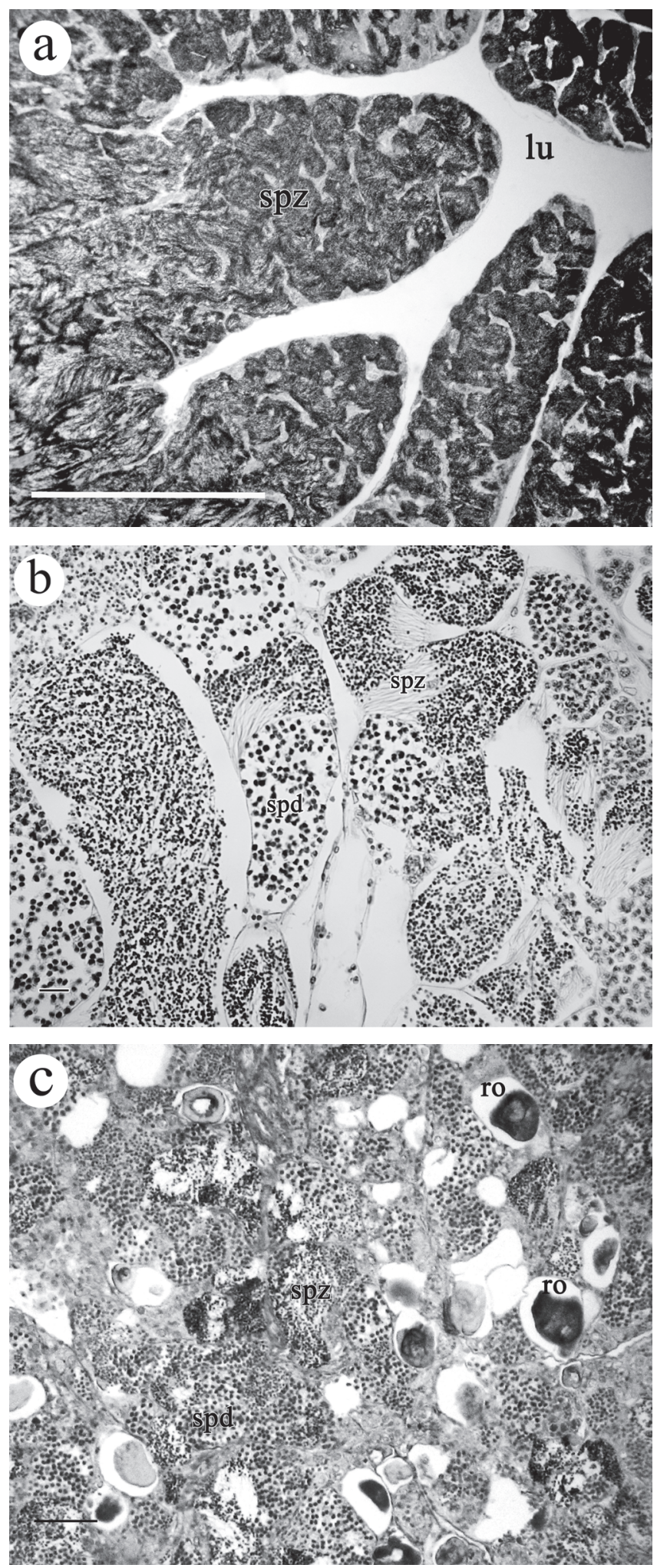

Fig. 2. Photomicrographs of histological sections from males Alphestes afer gonads. (a), (b) Section from a ripe male (a - bar $=300 \mu \mathrm{m}, 15.1 \mathrm{~cm} T_{\mathrm{r}}$; September 2008; b - bar $=37 \mu \mathrm{m}, 19.0 \mathrm{~cm}$ $T_{\mathrm{L}}$; August 2009). (c) Section from a ripening male with residual previtellogenic oocytes (bar $=50 \mu \mathrm{m} ; 21 \mathrm{~cm} T_{\mathrm{L}}$; June 2009). lu = lumen, $\mathrm{spz}=$ spermatozoa; $\mathrm{ro}=$ residual oocytes. 
emergence of spermatogonias and primary spermatocytes. During resting period of females, males were not found (MarchJune 2008; March-May 2009). Resting males were found only during January, February and June 2009 (Fig. 8). Immature males were not observed during the study.

The $I_{\mathrm{G}}$ was positively related to size for mature males (Spearman rank $R_{\mathrm{S}}=0.51 ; P<0.05$ ) and was inversely and weakly related to size for mature females (Spearman $\operatorname{rank} R_{\mathrm{S}}=$ $-0.14 ; P=0.43$ ), during reproductive period from August to October in both years. Some males were mature at $12 \mathrm{~cm} L_{\mathrm{T}}$ but $I_{\mathrm{G}}$ started to increase after $15 \mathrm{~cm} L_{\mathrm{T}}$ (Fig. 9).

There were significant differences among size classes in gonadal stages of females, males (immature, ripening, ripe, spent, and resting), bisexuals females (immature) and transitional females (resting, ripe and spent) (Kruskal-Wallis, $P<0.05 ; \mathrm{df}=9$ ).

Sex-ratio (females:males) was 0.94:1 during the spawning season period (August to October) and frequency distribution of males and females did not vary between 2008 and 2009 ( $\chi^{2}$; $P=0.589)$. Sex ratio per size classes showed the trend observed in size frequency distribuition (Fig. 6), with a clear tendency for males in smaller size classes and females in larger classes. Frequency of mature females and mature males also did not vary between classes where overlap occurred $\left(18-23 \mathrm{~cm} L_{\mathrm{T}}\right)$ $\left(\chi^{2} ; P=0.06\right)($ Table 5$)$.

The $I_{\mathrm{G}}$ mean of breeding males was 3.8 and the Alphestes afer sperm competition rank was (3) indicating that it is an

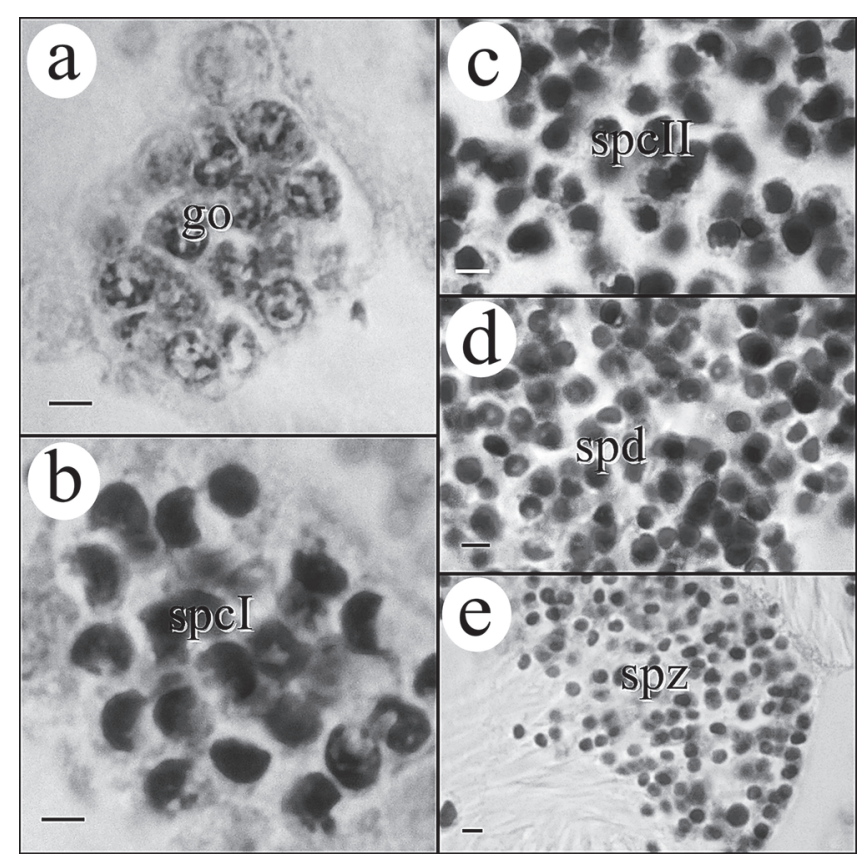

Fig. 3. Photomicrographs of a histological section from male Alphestes afer spermatogenesis stages. (a), go = spermatogonias, (b), spcI = spermatocytes in first stage (bar $=5 \mu \mathrm{m}) ;(\mathrm{c}), \mathrm{spcII}=$ secondary spermatocytes $(\mathrm{bar}=2.5 \mu \mathrm{m})$; (d), spd $=$ spermatides $($ bar $=2 \mu \mathrm{m}) ;(\mathbf{e}), \mathrm{spz}=$ spermatozoa $($ bar $=2 \mu \mathrm{m})\left(18.6 \mathrm{~cm} T_{\mathrm{L}} ;\right.$ September 2009).
Table 3. Gonads of Alphestes afer in bisexual phases according to histological criteria. F(Im), immature female; F, ovarian phase of resting, ripening, ripe and spent female; $\mathrm{Fbi}(\mathrm{Im})$, immature bisexual phase of female; $\operatorname{Tr}(\mathrm{Re})$, transitional phase of resting female; $\operatorname{Tr}(\mathrm{Rp})$, transitional phase of ripe female; $\operatorname{Tr}(\mathrm{Sp})$, transitional phase of spent female; $\mathrm{M}$, testicular phase of ripening, ripe, spent and resting male; $\mathrm{O} 1$, primary growth stage oocyte; $\mathrm{O} 2$, cortical alveolus stage oocyte; $\mathrm{O} 3$, vitellogenic stage oocyte; MB, muscle bundle; ST, spermatogenic issue; SS, sperm sinus; OD, degenarating ovarian tissue. +, present; - absent, +/-, present or absent.

\begin{tabular}{lccccccc}
\hline $\begin{array}{l}\text { Gonad } \\
\text { phase }\end{array}$ & O1 & O2 & O3 & MB & ST & SS & OD \\
\hline F(Im) & + & - & - & - & - & - & - \\
F & + & + & + & $+/-$ & - & - & + \\
Fbi(Im) & + & - & - & - & + & - & + \\
$\operatorname{Tr}(\operatorname{Re})$ & + & - & - & $+/-$ & + & $+/-$ & + \\
$\operatorname{Tr}(\mathrm{Rp})$ & - & + & + & - & + & - & + \\
$\operatorname{Tr}(\mathrm{Sp})$ & - & - & + & + & + & - & + \\
$\mathrm{M}$ & - & - & - & - & + & + & - \\
\hline
\end{tabular}

aggregating species that spawn in pair or groups. The category of sexual pattern was protogynous or unconfirmed gonochorism (Table 1).

\section{Discussion}

In low latitudes, grouper species spawn between early spring and summer (Shapiro, 1987; Ferreira, 1993; Heemstra \& Randall, 1993). Gonadal stages and $I_{\mathrm{G}}$ of Alphestes afer in Brazilian reefs indicated that spawning activity occurred earlier, between late winter and spring. This periodicity was confirmed by histological evidence as well as $I_{\mathrm{G}}$ analysis. Multiple-spawning during this period was indicated by asynchronous oocyte development in females and continuous spermiogenesis in males, a pattern often observed in other epinephelids (Ferreira, 1995).

During the reproductive period in Brazilian reefs, running ripe $A$. afer females and males were observed, indicating that spawning occurred within the fishing area. Males were absent in samples collected from March to June 2008 and from March to May 2009, a period during which they were most likely in the resting phase as observed for females and males collected during June 2009. The absence of males may be the result of a spatial segregation of sexes during non active reproductive periods. Robertson \& Choat (1974) noted that temporary territorial males of Thalassoma lunare (protogynous hermaphrodite) appeared only during the spawning season. Some species of groupers have also shown co-occurrence of males and females only during the reproductive period indicating spatial segregation with females in shallow water and males in deeper areas during the resting period (Coleman et al. 1996; Sadovy, 1994; Shapiro, 1987). However, the fishing area covered in this study was broad and reached the deeper limits of the species known depth distribution, if this movement occurs, it should 
be to shallower areas as traps start to be deployed at $30 \mathrm{~m}$ depth. It was observed that $A$. afer disappeared altogether from shallow reefs ( $3 \mathrm{~m}$ deep) located in Tamandaré (Pernambuco Coast, Brazil), during the spawning season but individuals were observed during remaining periods of the year. As their sex was not determined it is not possible to conclude if those individuals belonged to one or both sexes.
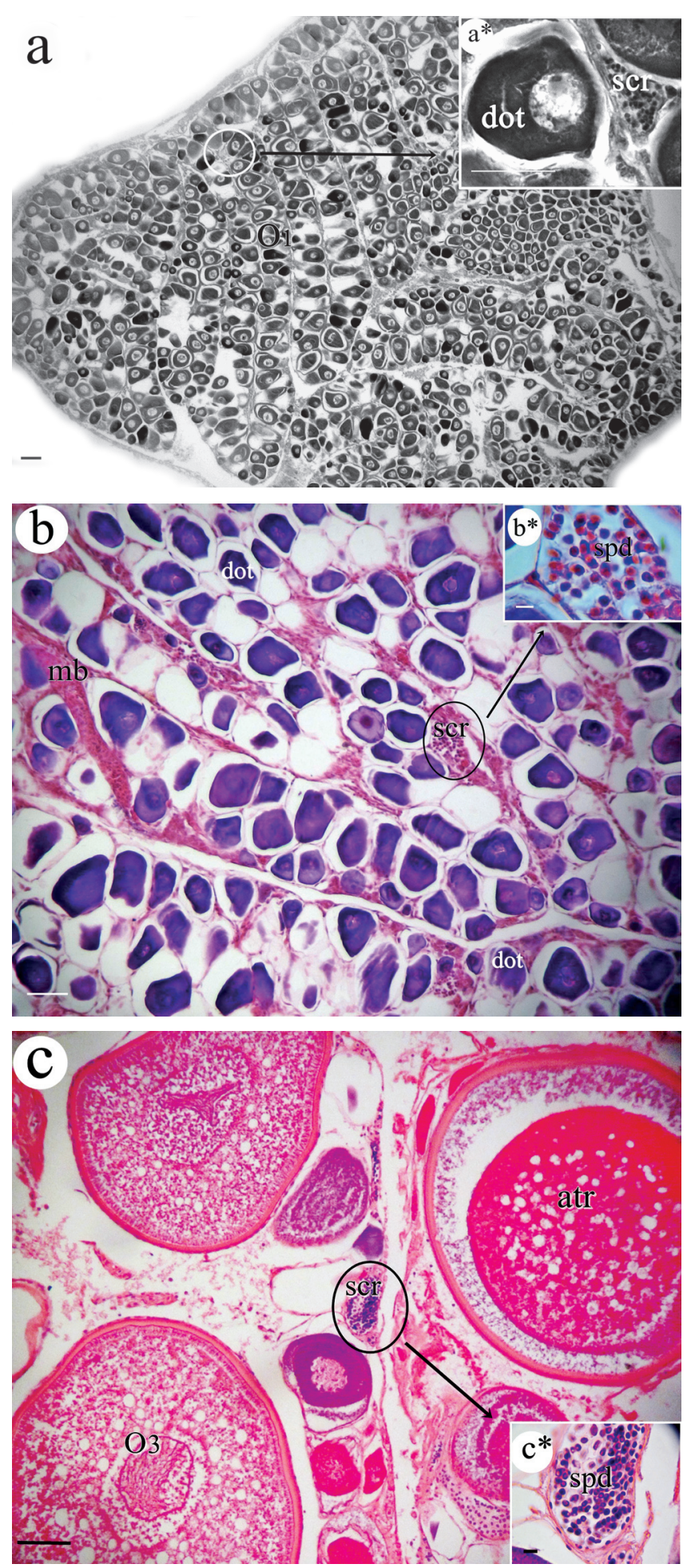

Table 4. Classification of Alphestes afer by gonad class and size from March 2008 until February 2010. Fbi(Im), bisexual phase of immature female; F, ovarian phase of resting, ripe and spent female; $\operatorname{Tr}(\mathrm{Re})$, transitional phase of resting female; $\operatorname{Tr}(\mathrm{Rp})$, transitional phase of ripe female; $\operatorname{Tr}(\mathrm{Sp})$, transitional phase of spent female; $\mathrm{M}$, testicular phase of ripe, spent and resting male; $\left({ }^{*}\right)$ individuals without $\mathrm{MB} ;\left({ }^{* *}\right)$ individuals with spermatic sinus $($ Total $=257)$.

\begin{tabular}{lccccccc}
\hline $\mathrm{LT}(\mathrm{cm})$ & $\mathrm{F}(\mathrm{Im})$ & $\mathrm{F}$ & $\mathrm{Fbi}(\mathrm{Im})$ & $\operatorname{Tr}(\operatorname{Re})$ & $\operatorname{Tr}(\mathrm{Rp})$ & $\operatorname{Tr}(\mathrm{Sp})$ & $\mathrm{M}$ \\
\hline $11 \mid-12$ & 2 & & & & & & \\
$12 \mid-13$ & 2 & & & & & & 3 \\
$13 \mid-14$ & 3 & & & & & & \\
$14 \mid-15$ & 2 & & & & & & 1 \\
$15 \mid-16$ & & & & & & & 4 \\
$16 \mid-17$ & 7 & 1 & 1 & & & & 4 \\
$17 \mid-18$ & 1 & & & $1\left(1^{* *}\right)$ & & & 8 \\
$18 \mid-19$ & 3 & 17 & & $5\left(1^{*} ; 3^{* *}\right)$ & 1 & & 11 \\
$19 \mid-20$ & & 34 & & $4\left(1^{*} ; 4^{* *}\right)$ & & & 10 \\
$20 \mid-21$ & & 46 & & & & & 9 \\
$21 \mid-22$ & & 28 & & & 1 & 1 & 6 \\
$22 \mid-23$ & & 19 & & 1 & & & 1 \\
$23 \mid-24$ & & 8 & & & & 1 & \\
$24 \mid-25$ & & 7 & & & & 1 & \\
$25 \mid-26$ & & 3 & & & & & \\
Total & 20 & 163 & 1 & 11 & 2 & 3 & 57 \\
\hline
\end{tabular}

\section{Pathways of protogynous hermaphroditism}

A single previous, available study for $A$. afer is that of Smith (1959) who classified it as a protogynous hermaphrodite and reported females ranging from 13.2 to $23.5 \mathrm{~cm} L_{\mathrm{T}}$ and a single male of $21.3 \mathrm{~cm} L_{\mathrm{T}}$. Our study from Brazilian reefs showed mature males from 12 to $22 \mathrm{~cm} L_{\mathrm{T}}$ and mature females from 16 to $25 \mathrm{~cm} L_{\mathrm{T}}$, indicating that males are in average smaller than females. Also, first maturity size of males at $12 \mathrm{~cm} L_{\mathrm{T}}$ was inferior to the size of first maturity of females at $18 \mathrm{~cm} L_{\mathrm{T}}$. Males smaller than $17 \mathrm{~cm} L_{\mathrm{T}}$ were considered primary males because they did not show any signs of previous reproduction as females. The suggested reproductive pathways for A. afer are shown in Fig. 10. Reports of species,

Fig. 4. (left column) Females with bisexual and transitional phases in Alphestes afer. (a) Section showing a gonad in bisexual phase of immature female $(\mathrm{bar}=50 \mu \mathrm{m})\left(16.1 \mathrm{~cm} T_{\mathrm{L}}\right.$; May 2008). ( $\left.a^{*}\right)$ Detail of spermatic crypt in major magnification of same specimen $(1000 x$; bar $=20 \mu \mathrm{m})$. (b) Section showing a gonad in transitional phase of resting female with sperm crypts spread among ovarian tissue $(\mathrm{bar}=50 \mu \mathrm{m})\left(19.8 \mathrm{~cm} T_{\mathrm{L}}\right.$; May 2009). (b*) Detail of spermatic crypt $(1000 x ;$ bar $=2 \mu \mathrm{m})$. (c) Section of ovary showing transitional phase of spent female with sperm crypts around vitellogenic stage oocyte (bar $=50$ $\mu \mathrm{m})\left(21.1 \mathrm{~cm} T_{\mathrm{L}}\right.$; October 2009). (c*) Detail of spermatic crypt $(1000 x$, bar $=2 \mu \mathrm{m}) \mathrm{O}_{1}=$ primary growth stage oocyte; dot $=$ degenerating ovarian tissue, $\mathrm{scr}=$ sperm crypts; $\mathrm{mb}=$ muscle boundle; $\mathrm{O} 3$ = vitellogenic stage oocyte; atr = atretic vitellogenic oocytes; $\mathrm{spd}=$ spermatides. 
Table 5. Number of females and males sampled and sex ratio (female : male) by size for $A$. afer during reproductive period in 2008 and 2009.

\begin{tabular}{ccccccc}
\hline $\begin{array}{c}L_{\mathrm{T}} \\
(\mathrm{cm})\end{array}$ & $\begin{array}{c}\text { Females } \\
2008\end{array}$ & $\begin{array}{c}\text { Males } \\
2008\end{array}$ & $\begin{array}{c}\text { Sex Ratio } \\
2008\end{array}$ & $\begin{array}{c}\text { Females } \\
2009\end{array}$ & $\begin{array}{c}\text { Males } \\
2009\end{array}$ & $\begin{array}{c}\text { Sex Ratio } \\
2009\end{array}$ \\
\hline $12 \mid-13$ & & 3 & & & & \\
$13 \mid-14$ & & & & & & \\
$14 \mid-15$ & & 1 & & & & \\
$15 \mid-16$ & & 2 & & & 1 & \\
$16 \mid-17$ & & 3 & & & & \\
$17 \mid-18$ & & 3 & & & 1 & \\
$18 \mid-19$ & 2 & 2 & $1: 1$ & & 4 & \\
$19 \mid-20$ & & 2 & & 2 & 3 & $0.66: 1$ \\
$20 \mid-21$ & 1 & & & 5 & 4 & $1.25: 1$ \\
$21 \mid-22$ & 6 & 1 & $6: 1$ & 4 & 2 & $2: 1$ \\
$22 \mid-23$ & 2 & & & 2 & 1 & $2: 1$ \\
$23 \mid-24$ & 1 & & & 3 & & \\
$24 \mid-25$ & & & & 1 & & \\
$25 \mid-26$ & 1 & & & 1 & & \\
\hline Total & 13 & 17 & $0.76: 1$ & 18 & 16 & $1.12: 1$ \\
\hline
\end{tabular}

in which males are consistently smaller than females, have been related to the development of primary males that do not pass through a stage of functional, adult female, and develop through juvenile phase (Munday et al., 2006). This process, called juvenile sex inversion, has been previously reported for sparids (Francis \& Pankhurst, 1988) as well as for serranids (Ferreira, 1995; Bhandari et al., 2004; Liu \& Sadovy, 2004). These males function only as one sex during their lifetime and are not functional sex-changers according to Sadovy \& Shapiro (1987). They also exhibit the same testicular morphology as large males of the genera Cephalopholis and

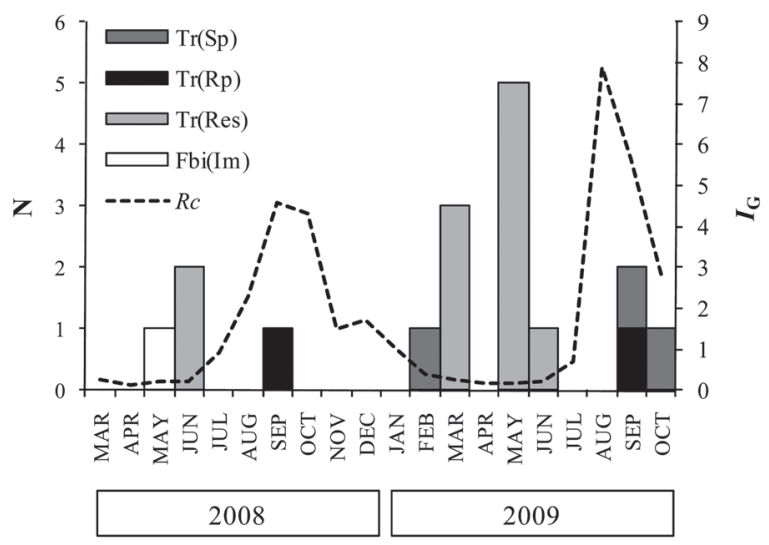

Fig. 5. Monthly distribution of number $(\mathrm{N})$ of females of Alphestes afer in sex change during reproductive cycle (from March 2008 up to October 2009); $I_{G}$, gonadosomatic index. Fbi (Im), inactive bisexual phase of female; $\operatorname{Tr}(\operatorname{Re})$, transitional phase of resting; $\operatorname{Tr}(\mathrm{Rp})$, transitional phase of ripe; $\operatorname{Tr}(\mathrm{Sp})$, transitional phase of spent female; $R c$, reproductive cycle $(n=17)$.

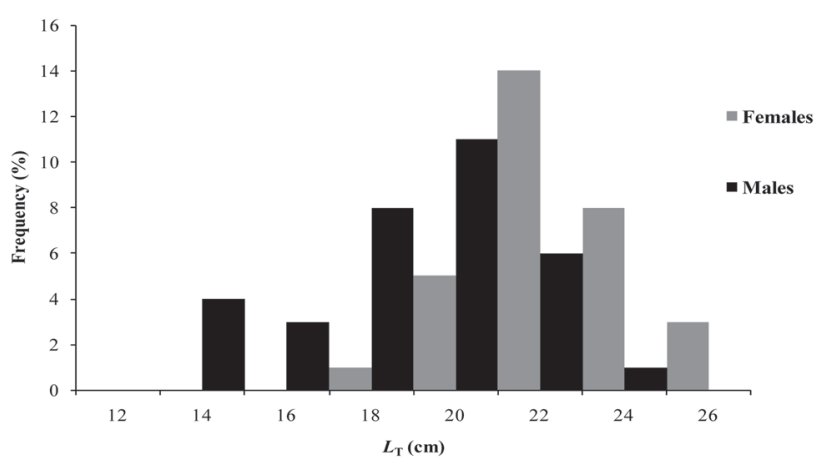

Fig. 6. Size-frequency distribution of females and males of $A$. afer during the reproductive period of 2008 and 2009. (Males, $\mathrm{n}=33$; Females, $\mathrm{n}=31$ ).

Plectropomus (Ferreira, 1993; Chan \& Sadovy, 2002; Liu \& Sadovy, 2004). One individual of $A$. afer presented degenerating tissue of primary oocytes as well as proliferation of spermatogenic tissue, and was considered an immature bisexual female (Fig. 10). This term has been used by several authors (Smith, 1965; Chan \& Sadovy, 2002; Liu \& Sadovy, 2004) when gonads present a combination of immature
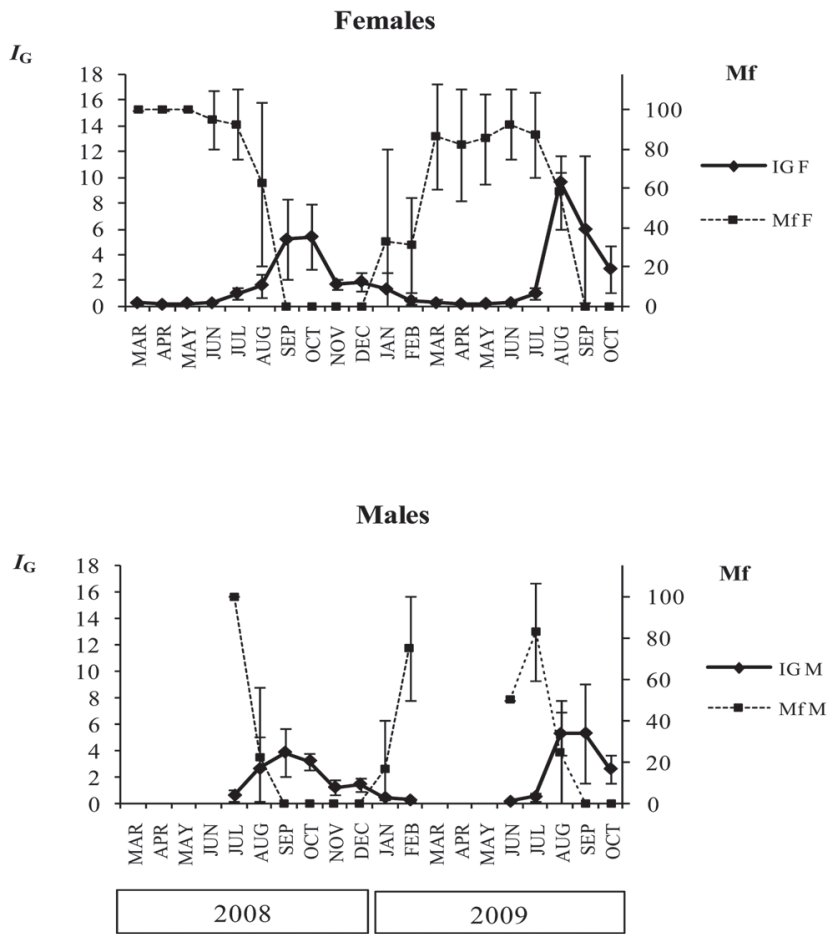

Fig.7. Monthly variation analysis of the gonasosomatic index $\left(I_{G}\right)$ of Females $\left(I_{G} \mathrm{~F} ; \mathrm{n}=200\right)$ Males $\left(I_{G} \mathrm{M} ; \mathrm{n}=57\right)$; and fat deposited in the mesenteries (Mesenteric fat - Mf F; Mf M) of Alphestes afer from Pernambuco coast. Error bars show standard deviation of original data. 


\section{Females}

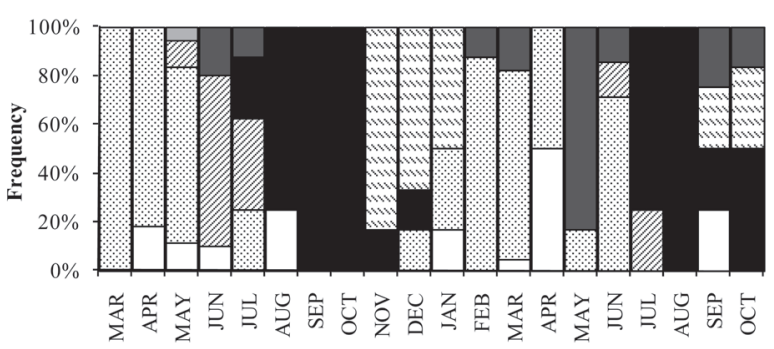

Males

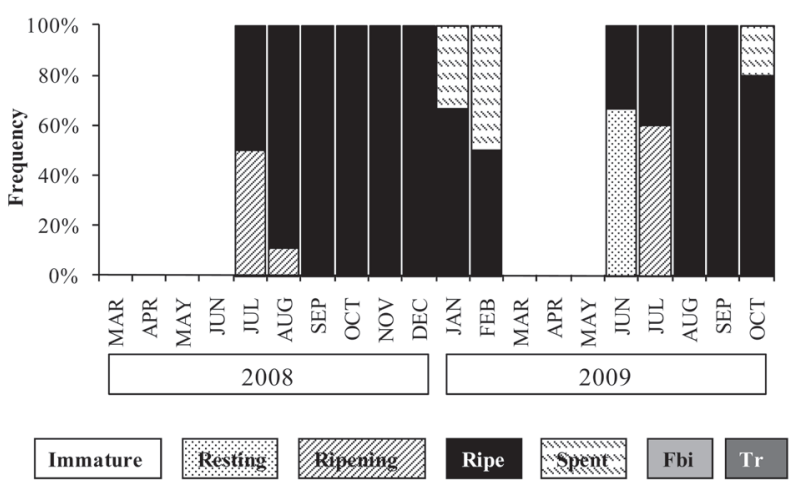

Fig. 8. Monthly distribution percentages of gonadal stages per females $(\mathrm{n}=183)$, immature bisexual female $(\mathrm{Fbi})(\mathrm{n}=1)$, transitionals $(\operatorname{Tr})(n=16)$ and males $(n=57)$ from Pernambuco coast.

testicular tissue and immature ovarian tissue (Sadovy de Michetson \& Liu, 2008).

Alphestes afer in Brazilian reefs showed functional sex change, that is, from functional female to male. Individuals considered to be secondary males presented developing sperm crypts in ovarian tissue classified as resting, ripe and spent, this last two showing evidences of previous vitellogenic activity. The transitional females showed degeneration of vitellogenic stage oocytes, the proliferation of testicular tissue and muscle bundles (Table 3 ). The presence of muscle bundle was also observed, what could be an additional evidence as those structures have been considered a reliable indicator for determining previous female function in Cephalopholis boenak (Liu \& Sadovy, 2004). Males were always smaller than females, but some of the transitionals individuals presented sizes close to the maximum size observed for males. It was noted however, that those were apparently in early stages of transition, with few sparse sperm crypts (Nakamura et al., 2007). A flexible mechanism that incorporates social signs about the size and abundance of conspecifics, as well as state-dependent information about the individual to achieve timing of sex change, has been proposed for hermaphroditic species as an adaptive advantage (Sattar et al., 2008). This mechanism could also explain the wide range at which $A$. afer individuals may change sex from female to male.

\section{Population structure and mechanisms of sex change}

Size-advantage model proposes that selection for sex change exists when reproductive success increases with size or age more rapidly for one sex than for the other (Avise \& Mank, 2009; Erisman et al., 2009). Also, sex change is favored when an individual reproduces most efficiently as one sex when young or small, and most efficiently as the opposite sex when it gets older or larger (Shapiro, 1988; Munday et al., 2006). The intensity of sexual selection for protogyny varies inversely with local population size and the ability of small males to access females in matings (Warner, 1982).

In mating with random pairing, it should be advantageous to be a male when small (thus mating with larger individuals) and female when large (high capacity for egg production) (Warner, 1984). Moreover, small males increase their reproductive success by accessing females via group spawning (Erisman et al., 2009). The mating pattern for $A$. afer is not known, but for the congener $A$. immaculatus, pair spawning has been reported by Erisman et al. (2009).

Erisman et al. (2009) proposed the sperm rank competition index $\left(S_{\mathrm{R}}\right)$ to evaluate intensity of sperm competition in groupers. They also suggested that higher indexes were observed for species with higher sperm competition, where gonochorism was progressively favoured against protogyny. For $A$. afer, $S_{\mathrm{R}}$, determined by the relative testes weights, was 3.8; this is an index considered high and related to species

\section{Females}
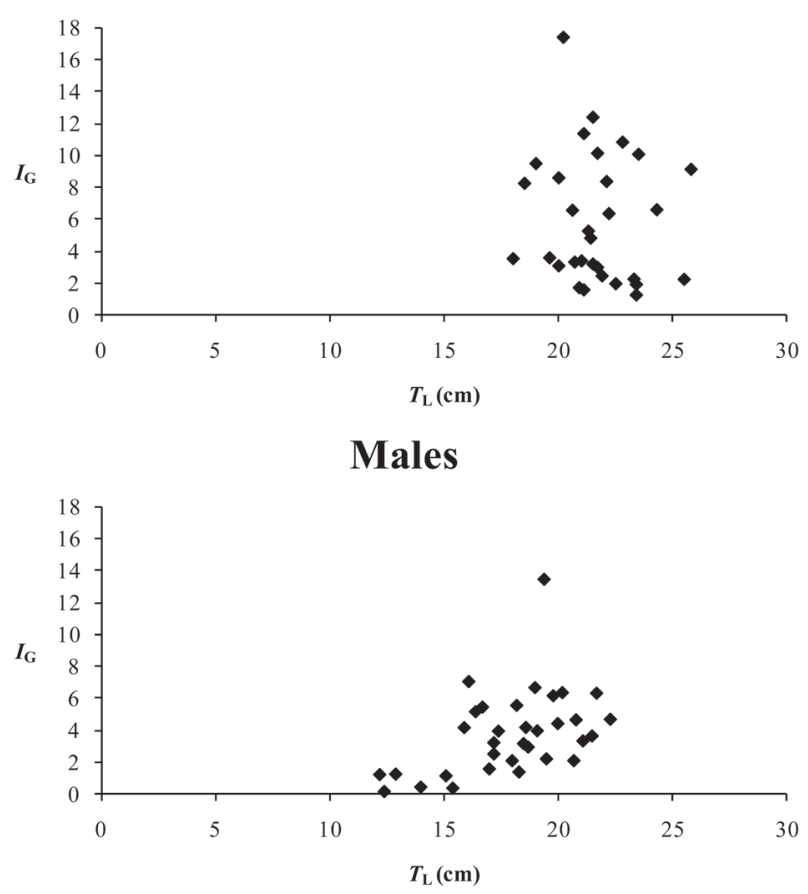

Fig. 9. Relationship between gonasosomatic index $\left(I_{\mathrm{G}}\right)$ and size $\left(T_{\mathrm{L}}\right)$ of ripe females $(\mathrm{n}=31)$ and males $(\mathrm{n}=33)$ of Alphestes afer during the reproductive peak (August up to September 2008, 2009). 

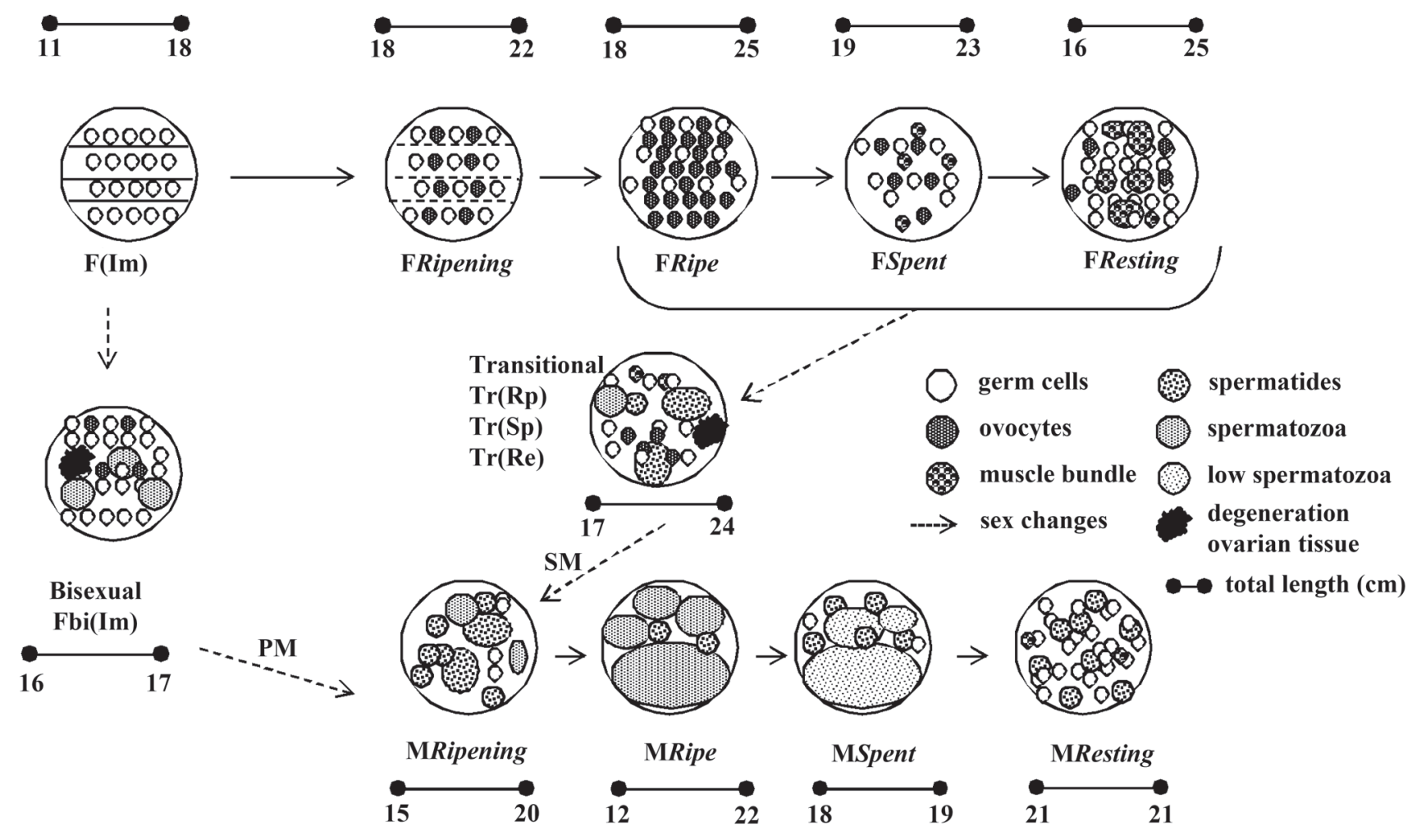

Fig. 10. Pathways of the reproductive cycle of Alphestes afer showing the steps of protogynous hermaphroditism steps according to histological evidences observed. The schematic figures represent a portion of the histological section observed in microscopic. Fbi (Im), immature bisexual female; $\operatorname{Tr}(\mathrm{Rp})$, transitional ripe; $\mathrm{TR}(\mathrm{Sp})$, transitional spent; $\mathrm{TR}(\mathrm{Re})$, transitional resting; PM, primary male; SM, secondary male.

that were protogynous or uncorfirmed gonochorist (Table 1). Indexes higher than 4.0 have been found in gonochoristic species. According to this model, species with intense sperm competition have large testes and losses of sex change (shifts in sexual pattern from protogyny to gonochorism) are related to shift in the mating group structure from paired to group spawning (Erisman et al., 2009).

For A. afer, the development of both primary and secondary males was found. However, males were consistently smaller than females and matured at smaller sizes. These characteristics, added to the high sperm competition index, suggest that this species, while retaining the option of a protogynous pattern, has a reproductive strategy similar to gonochorist epinephelids.

Generally, in protogynous hermaphrodites's populations bigger males represent older individuals while smaller females represent the youngest (Choat \& Robertson, 2002; Shapiro, 1987). Sex related differences in growth rates have been reported for several species, and so it is possible that growth rates are reduced after sex change from female to male in $A$. afer. In this case, smaller males could represent older individuals for their size classes than females of the same size. Effects of fishing, truncating the size distribution, could also operate to reducing the maximum size of individuals in the population and also the size of sex transition, and thus increasing the size overlap of sexes (Sattar et al., 2008).

Variants of developmental pathways within the same species are common among protogynous hermaphrodites (Muñoz \& Warner, 2004; Rogers, 2003). This work showed that $A$. afer is a diandric protogynous hermaphrodite with two pathways, according to which male could have juvenile sex inversion (primary male) or sex inversion by functional female to secondary male. Further studies of age structure as well as social and mating systems of $A$. afer could provide more insights on the strategies of reproduction and consequences of fishing on populations.

\section{Acknowledgments}

We wish to thank J. L. L. Filho for support of Laboratory of Imunopatology Keizo Asami and C. Lima for their assistance in the histological preparations (Universidade Federal de Pernambuco - UFPE). We are grateful to fishers of Itamaracá, Recife, Tamandaré and São José da Coroa Grande for their help giving access to the landings and in collecting the samples. Special thanks to Instituto Chico Mendes - Centro de Pesquisa e Gestão de Recursos Pesqueiros do Litoral Nordeste (ICMBIO - CEPENE) for Laboratorial support. We also thank S. N. Leitão (UFPE) for 
use of laboratory facilities. Thanks to I. Estevão for help with samples. We thank Y. Sadovy de Mitcheson for her valuable comments and suggestions. This work was supported by grants from Conselho Nacional de Desenvolvimento Científico e Tecnológico (CNPq - 140166/ 2007-6).

\section{Literature Cited}

Avise, J. C. \& J. E. Mank. 2009. Evolutionary perspectives on hermphroditism in fishes. Sexual Development, 3: 152-163.

Beçak, W. \& J. Paulete. 1976. Técnicas de citologia e histologia. Ed. Livros Técnicos e Científicos S. A., São Paulo, 305p.

Bhandari, R. K., H. Komuro, M. Higa \& M. Nakamura. 2004. Sex Inversion of Sexually Immature Honeycomb Grouper (Epinephelus merra) by Aromatase Inhibitor. Zoological Science, 21: 305-310.

Carvalho-Filho, A. 1999. Badejos, chernes, garoupas e mero. Pp. 97- 111. In: Carvalho-Filho, A. (Ed.). Peixes da Costa Brasileira. Melro, São Paulo, 320p.

Chan, S. T. H. \& S. B. Yeung. 1983. Sex control and sex reversal in fish under natural conditions. Pp. 171-222. In: Hoar,W. S., D. J. Randal \& E. M. Donaldson (Eds.). Fish Physiology. London, New York.

Chan, T. T. \& Y. Sadovy. 2002. Reproductive biology, age and growth in the chocolate hind, Cephalopholis boenak (Bloch, 1790), in Hong Kong. Marine Freshwater Research, 53: 791-803.

Choat, J. H. \& D. R. Robertson. 2002. Age-based studies on coral reef fishes. Pp. 57-80. In: Sale, P.F. (Ed.). Coral reef fishes: Dynamics and diversity in a complex ecosystem. Academic Press, San Diego, 549p.

Coleman, F. C., C. C. Koening \& L. A. Collins. 1996. Reproductive styles of shallow water-groupers (Pisces: Serranidae) in the eastern Gulf of Mexico and the consequences of fishing spawning aggregations. Environmental Biology of Fishes, 47: 129-141.

Craig, M. T., P. Bartsch, P. Wirtz, \& P. C. Heemstra. 2006. Redescription and validation of Alphestes afer as an amphiAtlantic grouper species (Perciformes: Serranidae). Cybium, 30: 327-331.

Erisman, B. E., M. T. Craig \& P. A. Hastings. 2009. A phylogenetic test of the size-advantage model: evolutionary changes in mating behavior influence the loss of sex change in a fish lineage. The American Naturalist 174: E83-E99.

Ferreira, B. P. 1993. Reproduction of the inshore coral trout Plectropomus maculatus (Perciformes: Serranidae) from the Central Great Barrier Reef, Australia. Journal of Fish Biology 42: 831-844.

Ferreira, B. P. 1995. Reproduction of the common coral trout Plectropomus leopardus (Serranidae: Epinephelinae) from the Great Barrier Reef, Australia. Bulletin of Marine Science 56: 653-669.

Ferreira, B. P. \& M. Maida. 2006. Monitoramento dos recifes de coral do Brasil. MMA, Brasília, 120p.

Francis, M. P. \& N. W. Pankhurst. 1988. Juvenile sex inversion in the New Zealand snapper Chrysophrys auratus (Bloch and Schneider, 1801) (Sparidae). Australian Journal of Marine and Freshwater Research, 39: 625-631.

Heemstra, P. C. \& J. E. Randall. 1993. FAO species catalogue. Vol. 16. Groupers of the world (Family Serranidae, Subfamily Epinephelinae). An annoted and illustrated catalogue of the grouper, rockcod, hind, coral grouper and lyretail species known to date. FAO Fisheries Synopsis 125: 1-382.

Liu, M. \& Y. Sadovy. 2004. Early gonadal development and primary males in the protogynous epinepheline, Cephalopholis boenak. Journal of Fish Biology, 65: 987-1002.

Martins, A. S., G. Olavo \& P. A. S. Costa. 2005. A pesca de linha de alto mar realizada por frotas sediadas no Espírito Santo, Brasil. Pp 35-55. In: Costa, P. A., S. A. S. Martins \& G. Olavo (Eds.). Pesca e potenciais de exploração de recursos vivos na região central da Zona Econômica Exclusiva Brasileira. Museu Nacional, Rio de Janeiro, 247p.

Munday, P. L., P. M. Buston \& R. R. Warner. 2006. Diversity and flexibility of sex-change strategies in animals. Trends in Ecology and Evolution 21: 89-95.

Muñoz, R. C. \& R. R. Warner. 2004. Testing a new version of the size-advantage hypothesis for sex change: sperm competition and size-skew effects in the bucktooth parrotfish, Sparisoma radians. Behavioral Ecology 15; 129-136.

Nagahama, Y. 1983. The functional morphology of teleost gonads. Pp. 223-275. In: Hoar, W. S., D. J. Randall \& E. M. Donaldson (Eds.). Fish Physiology, IX (Part A). London, Academic Press.

Nakamura, M., M. A. Alam, Y. Kobayashi \& R. K. Bhandari. 2007. Role of sex hormones in sex change of grouper. Special Issue: 23-27.

Robertson, D. R \& J. H. Choat. 1974. Protogynous hermaphroditism and social systems in labrid fish. Pp. 217-225. In: Cameron, A. M., B. M. Cambell, A. B. Cribb, R. Endean, J. S. Jell, O. A. Jones, P. Mather \& F. H. Talbot (Eds.). Proceedings of the $2^{\text {nd }}$ International Coral Reef Symposium. The Great Barrier Reef Committee, Brisbane, 744p.

Rogers, L. 2003. Odds-playing and the timing of sex change in uncertain environments: you bet your wrasse. Behavioral Ecology 14: 447-450.

Sadovy, Y. \& D. Y. Shapiro. 1987. Criteria for the diagnosis of hermaphroditism in fishes. Copeia 1: 136-156.

Sadovy, Y. \& P. L. Colin. 1995. Sexual development and sexuality in the Nassau grouper. Journal of Fish Biology, 46: 961-976.

Sadovy, Y. 1994. Grouper stocks in the western central Altantic: the need for management and management needs. Proceeding of the Annual Gulf and Caribbean Fisheries Institute, 43: 4364.

Sadovy de Mitcheson, Y. \& M. Liu. 2008. Functional hermaphroditism in teleosts. Fish and Fisheries, 9: 1-43.

Sattar, A. S., C. Jorgensen \& O. Fiksen. 2008. Fisheries-induced evolution of energy and sex allocation. Bulletin of Marine Science, 83: 235-250.

Shapiro, D. Y. 1981. Size, maturation and the social control of sex reversal in the coral reef fish Anthias squamipinnis (Peters). Journal of Zoology, 193: 105-128.

Shapiro, D. Y. 1987. Reproduction in groupers. Pp. 295- 327. In: Polovina, J. J. \& S. Ralston (Eds.). Tropical Snappers and Groupers - Biology and Fisheries Management. Westview Press, Colorado, 602p.

Shapiro, D. Y. 1988. Behavioral influences on gene structure and other new ideas concerning sex change in fishes. Environmental Biology of Fishes, 23(4): 283-297.

Smith, C. L. 1959. Hermaphroditism in some serranid fishes from Bermuda. Michigan Academic of Science, Arts and Letters, 54: 111-119.

Smith, C. L. 1965. The patterns of sexuality and classification of serranid fishes. American Museum of Novitates, 2207: 1-20.

Smith, W. M. L. \& M. T. Craig. 2007. Casting the Percomorph 
Net Widely: the importance of broad taxonomic sampling in the search for the placement of serranid and percid fishes. Copeia, 2007, 1: 35-55.

Warner, R. R. 1982. Mating systems, sex change and sexual demography in the rainbow wrasse, Thalassoma lucasanum. Copeia 1982: 653-661.

Warner, R. R. 1984. Mating behavior and hermaphroditism in coral reef fishes. American Scientis, 72: 128-136.

Yamamoto, T. 1969. Sex Differentiation. Pp. 111-174. In: Hoar, W. S. \& D. J. Randal (Eds.). Fish Physiology. London, New York, 485p.

Submitted October 8, 2010

Accepted June 6, 2011

Published September 16, 2011 